\title{
A NEW SPECIES OF SOLENIDIUM (ORCHIDACEAE) FROM ECUADOR
}

\author{
STIG DALSTRÖM $^{1}$ and W. MARK WhiTTEN ${ }^{2}$ \\ ${ }^{1}$ Marie Selby Botanical Gardens, 811 South Palm Avenue, Sarasota, FL 34236, USA \\ ${ }^{2}$ Herbarium (FLAS), Florida Museum of Natural History, University of Florida \\ P.O. Box 117800, Gainesville, FL 32611-7800, USA
}

\begin{abstract}
A new species from Ecuador; Solenidium portillae (Orchidaceae: Oncidiinae) is described, compared with the other two accepted species in the genus, and illustrated. A brief history of the genus is presented and a key to the species is provided.
\end{abstract}

RESUmEN. Se describe y se ilustra una nueva especie del Ecuador, Solenidium portillae (Orchidaceae: Oncidiinae), comparándola con las otras dos especies aceptadas en el género. Se presenta una breve historia del género y se proporciona una clave de las especies.

Key words / Palabras Clave: Ecuador, new species, Orchidaceae, Oncidiinae, Solenidium.

The genus Solenidium was created by Lindley (1846) based on a plant collected by Jean Linden in the forests of Pamplona, Colombia, in 1842. The species was named Solenidium racemosum Lindl. (Fig. 1A). The generic name refers to the canaliculated basal part of the lip (Sweet 1973). Lindley distinguished the genus from Oncidium and Brassia by the "narrow stalked wartless lip, three-lobed anther-bed, and very peculiar pollen masses, which are bent down upon their caudicle, while in the anther". It was found again in the same area in 1847, by Funck and Schlim, who were plant collectors for the Linden nursery in Belgium. This species remained unknown in collections and cultivation until rediscovered in Venezuela in 1973. It was collected near the Colombian border by Roberto Mejía and his assistant, known as "Ojo del Aguila" [eagle's eye] for his ability to spot orchid plants (Dunsterville 1983). The next species in the genus was actually described first, as Oncidium luna tum Lindl. (Fig. 1B) (Lindley 1838), and later transferred to Solenidium by Kränzlin (1922). It was based on a plant imported from Demerara [Guyana] by Loddiges. A few other species have been added to the genus but they have subsequently been transferred to other genera. It is rather difficult to define this little genus and a certain disagreement among taxonomists regarding where it belongs in Oncidiinae is apparent through its history. Very recently and rather surprisingly, DNA sequence analysis revealed that its closest relatives are members of the genus Capanemia Barb. Rodr. (N. Williams, pers. comm.). Indeed, when the flower morphology of this group of species is studied, certain similarities in the peculiar column structure can be observed. A more thorough treatment, however, will be presented elsewhere. A third species was discovered recently in Ecuador, by the industrious collectors of Ecuagenera, and is described here.

Solenidium portillae Dalström \& Whitten, sp. nov.

FIG. 1C, 2

TYPE: ECUADOR: Carchi: Chical, $1500 \mathrm{~m}$, originally discovered by the collectors of Ecuagenera, and flowered in cultivation in Gainsville, Florida, USA, $M$. Whitten 1812 (Holotype: SEL).

Inter species generis Solenidii Lindl., labellum late ovatum differt.

Plant epiphytic. Pseudobulbs caespitose, blunt elliptic, ancipitous, more or less sulcate, unifoliate, ca. $4.5 \times 2 \mathrm{~cm}$, subtended basally by 3 to 4 distichous sheaths, the uppermost foliaceous. Leaves conduplicate, elliptic, acute, apiculate, ca. $10 \times 2 \mathrm{~cm}$. Inflorescences axillary, from the base of the uppermost sheaths, arching, 10 to 12 flowered, to $15 \mathrm{~cm}$ long racemes; bracts adpressed, scale-like $0.3-0.7 \mathrm{~cm}$ long. Pedicel with ovary 1.4-1.7 cm long. Flowers slightly campanulate, sepals and petals greenish yellow with red brown markings, lip white with red pur- 

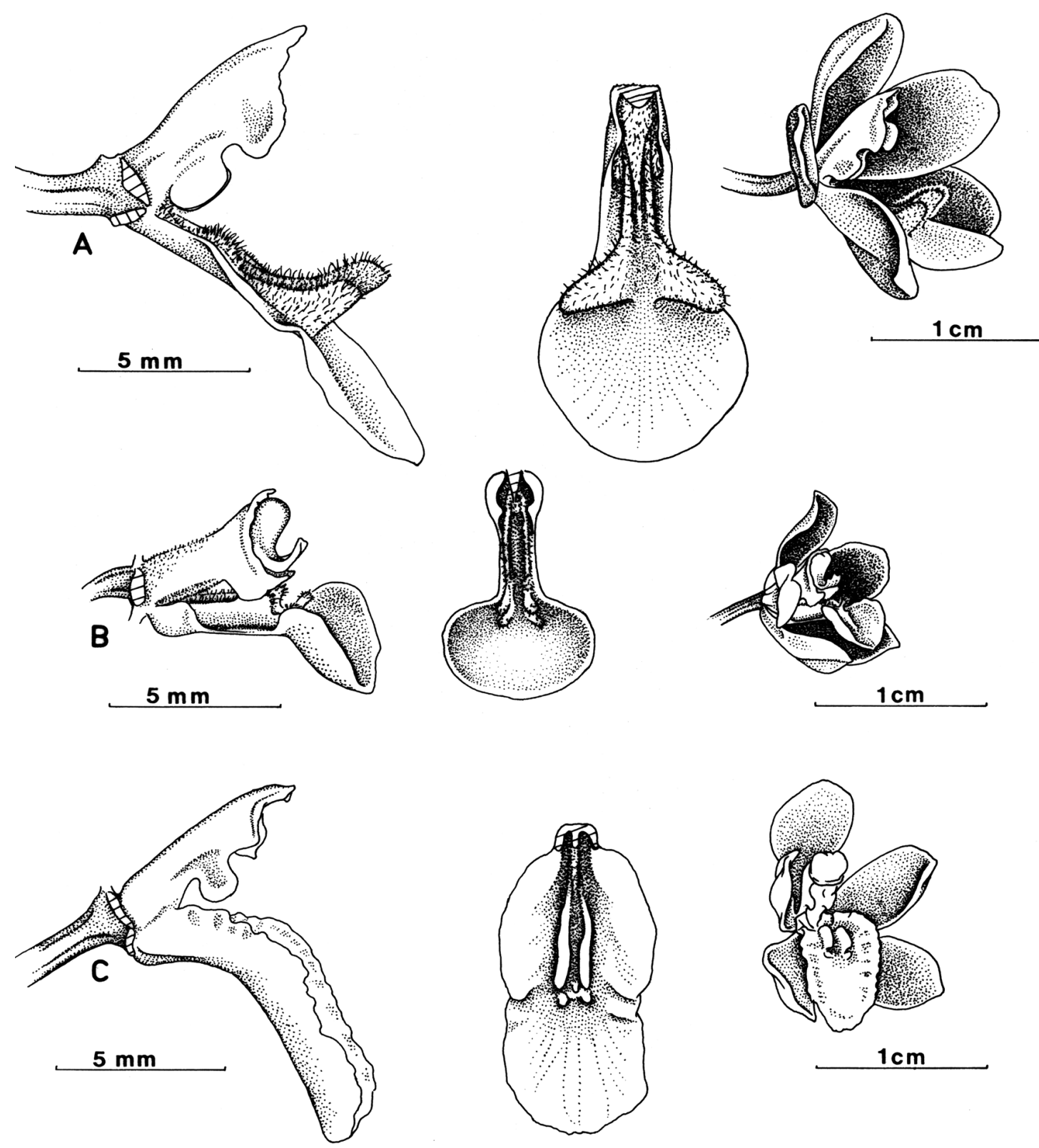

Fig. 1. A. Solenidium racemosum Lindl.; column and lip, lateral view; lip, dorsal view; flower, semi-lateral view. B. Solenidium lunatum (Lindl.) Kränzl.; column and lip, lateral view; lip, dorsal view; flower, semi-lateral view. C. Solenidium portillae Dalström \& Whitten; column and lip, lateral view; lip, dorsal view; flower, semi-lateral view. Illustration Vouchers: A, Linden 1264 (K-L, W). B, SEL 85-1156. C, M. Whitten 1812 (SEL).

ple specks and spots along the margins, column whitish with red purple stripes and spots and yellow apices of the lateral lobes, anther cap light yellow; dorsal sepal slightly unguiculate, rounded obovate, entire, ca. $1 \times 0.5 \mathrm{~cm}$; lateral sepals similar, slightly oblique $c a .1 \times 0.4 \mathrm{~cm}$; petals obovate, acute, entire, slightly oblique basally, ca. $1 \times 0.4 \mathrm{~cm}$; lip rigidly attached to the base and lateral flanks of the column and through a short, central, longitudinal, fleshy keel, rounded, ovate to weakly trilobate, lateral lobes indistinct, erect, slightly undulate, lamina slightly curved away from the column, shallowly concave, slightly 


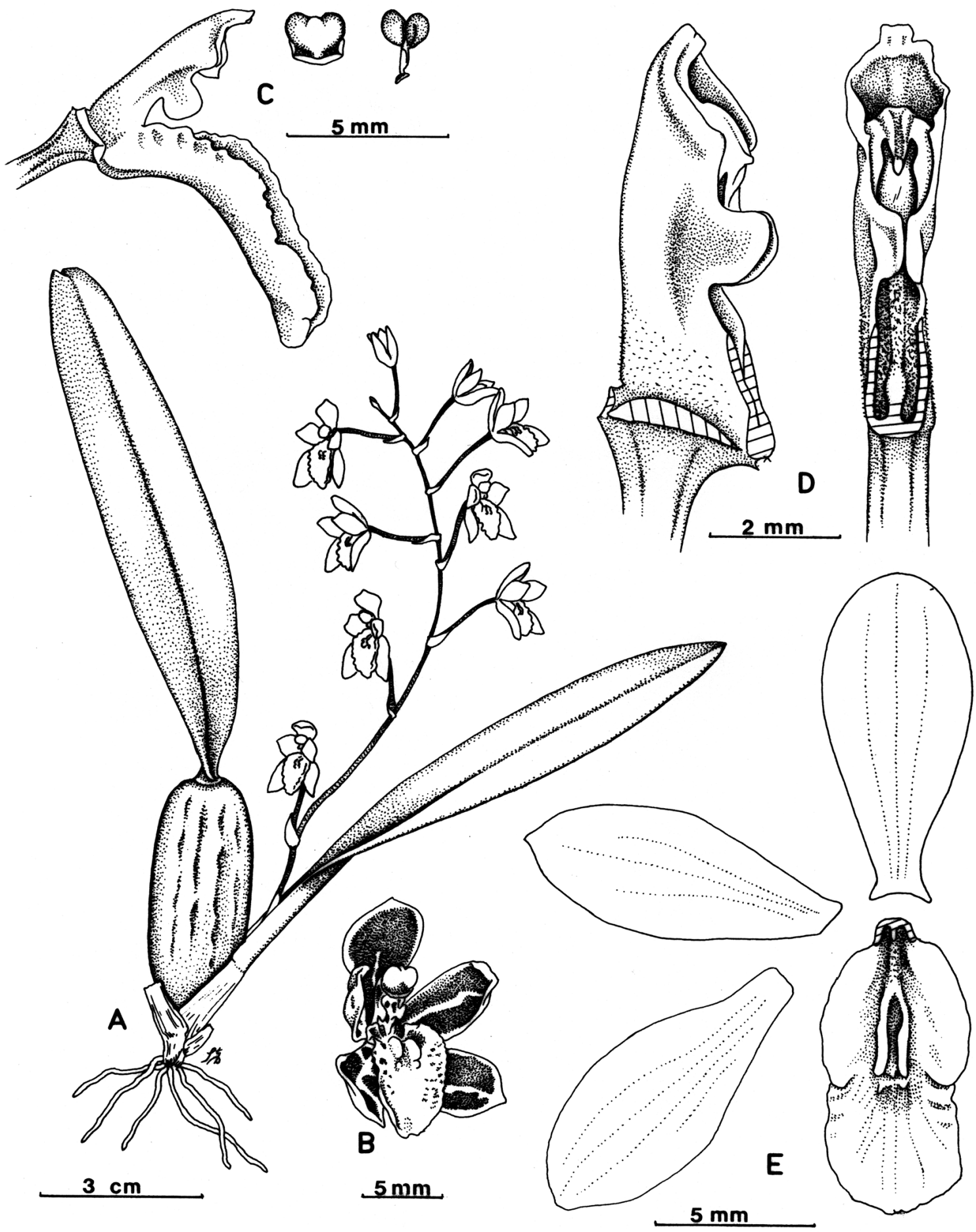

Fig. 2. Solenidium portillae Dalström \& Whitten. A. Plant habit. B. Flower, semi-lateral view. C. Column and lip, lateral view; anther cap and pollinarium, dorsal view. D. Column, lateral and ventral view. E. Floral diagram. ILLUSTRATION VOUCHER: M. Whitten 1812 (SEL). 
undulate, obtuse to praemorse, $0.9 \times 0.5 \mathrm{~cm}$; callus of a central, fleshy, pubescent short keel with two glabrous, longitudinal, fleshy keels emerging from ca. $0.2-0.3 \mathrm{~cm}$ above the base and extending onto the base of the lamina, terminating bluntly, with a pair of small, fleshy knobs above and some additional minor median denticles; column shortly clavate, pubescent basally and ventrally, canaliculated ventrally, with a pair of two distinct, rounded lobes and a well developed, entire anther hood, $0.6 \mathrm{~cm}$ long; anther cap bilobulate, with an intermediate lobule, broadly and shortly rostrate with a revolute edge; pollinarium of two, cleft, pyriform pollinia on a narrowly elongate obovate, $c a .0 .13 \mathrm{~cm}$ long stipe on a flat viscidium.

This species is placed in Solenidium because of great morphological similarities in plant habit and the flower morphology, particularly the column, anther cap and pollinarium structure.

Solenidium portillae is distinguished from the other two species in the genus by the broadly ovate and shallowly concave lip.

HaвiтAт: An epiphyte in wet, lower to middle elevation cloud forests on the western slopes of the Andes in northern Ecuador and probably Colombia.

FLOWERING SEASON: August, in cultivation.

PARATYPES: A color transparency of a single flower, by Rodrigo Escobar, Medellín (SEL) without any additional information, indicates that this species may possibly also be found in Colombia.

ETymology: Named in honor of José Portilla, owner of the orchid nursery Ecuagenera in Gualaceo, who have contributed substantially to the knowledge of the orchids in Ecuador.

\section{KEY TO THE SPECIES OF SOLENIDIUM}

1a. Column of the flower with a pair of rounded, basal ventral lobes; lip narrowly cuneate basally

1b. Column of the flower with ventral lobes, or wings, in the middle or near the apex; lip sub-saccate with basal lobes clasping or fused to the basal and lateral flanks of the column

2

2a. Column with apical, hatchet-shaped wings; lip strongly pandurate to hatchet shaped and with the apex of the callus pilose S. lunatum

2b. Column with rounded, ventral lobes in the middle; lip broadly ovate and apex of the callus glabrous ...... S. portillae

\section{ACKNOWLEDGMENTS}

We thank Carl Luer for help with the Latin diagnosis, and the herbarium staff at Kew, Vienna and Selby Gardens for their support.

\section{Literature Cited}

Dunsterville G. C. K. and E. 1983. Solenidium racemosum - The Return of a Prodigal Son. Amer. Orchid Soc. Bull. 11: 1157-1160.
Kränzlin, F. 1922. Engler, Planzenreich 4. 50, Heft 80: 316.

Lindley, J. 1838. Edward's Bot. Reg. 23: sub t. 1920.

Lindley, J. 1846. Orchidaceae Lindenianae, or Notes upon a collection of Orchids formed in Colombia and Cuba, by Mr. J. Linden. Bradbury and Evans, Whitefriars, London.

Sweet, H. 1973. Solenidium racemosum Lindl. Orquideología 8: 90-93. 